THE OPERAS OF ALBAN BERG/LULU 


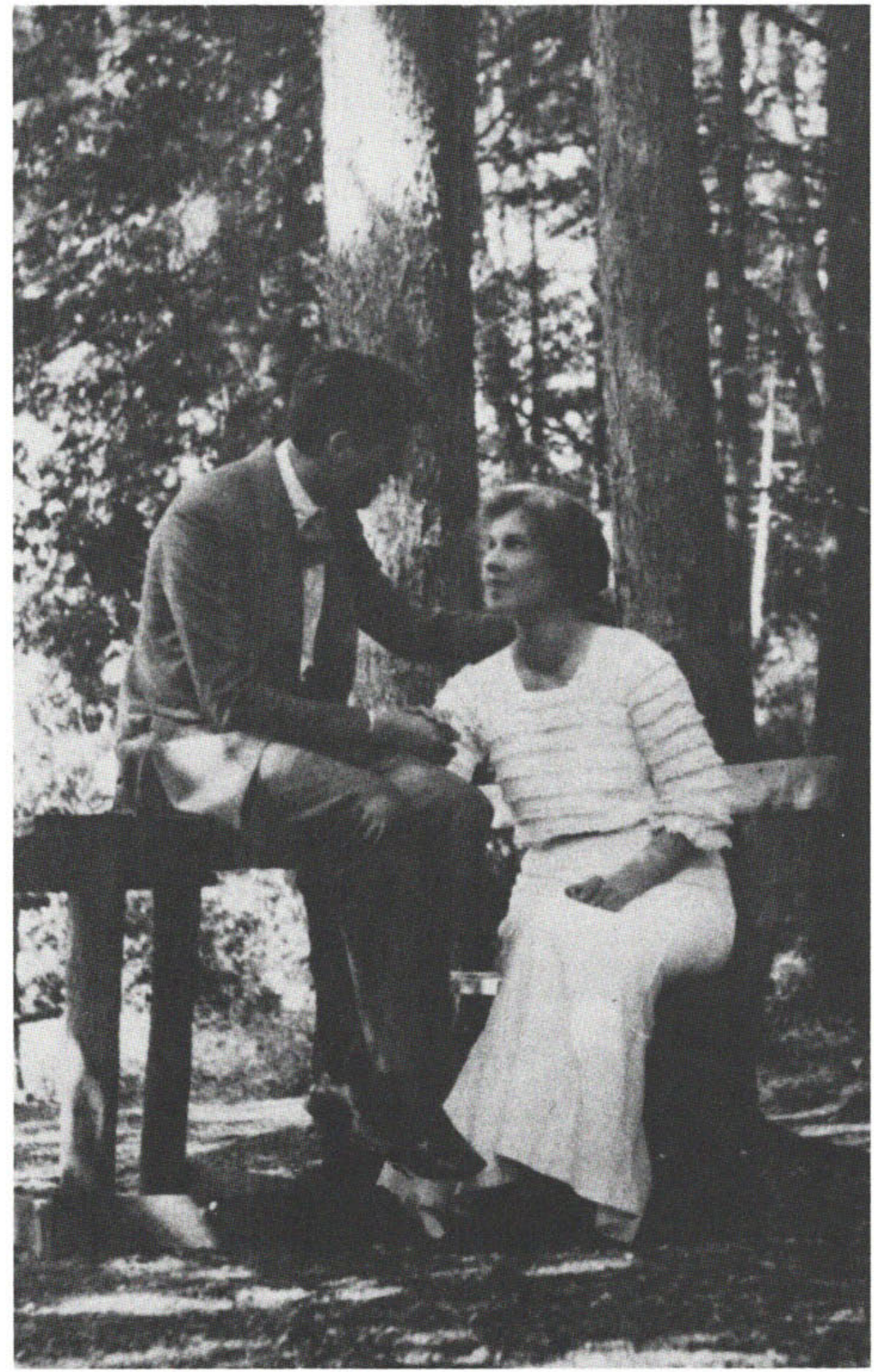

Frontispiece. Alban and Helene Berg. 


\section{THE OPERAS OF}

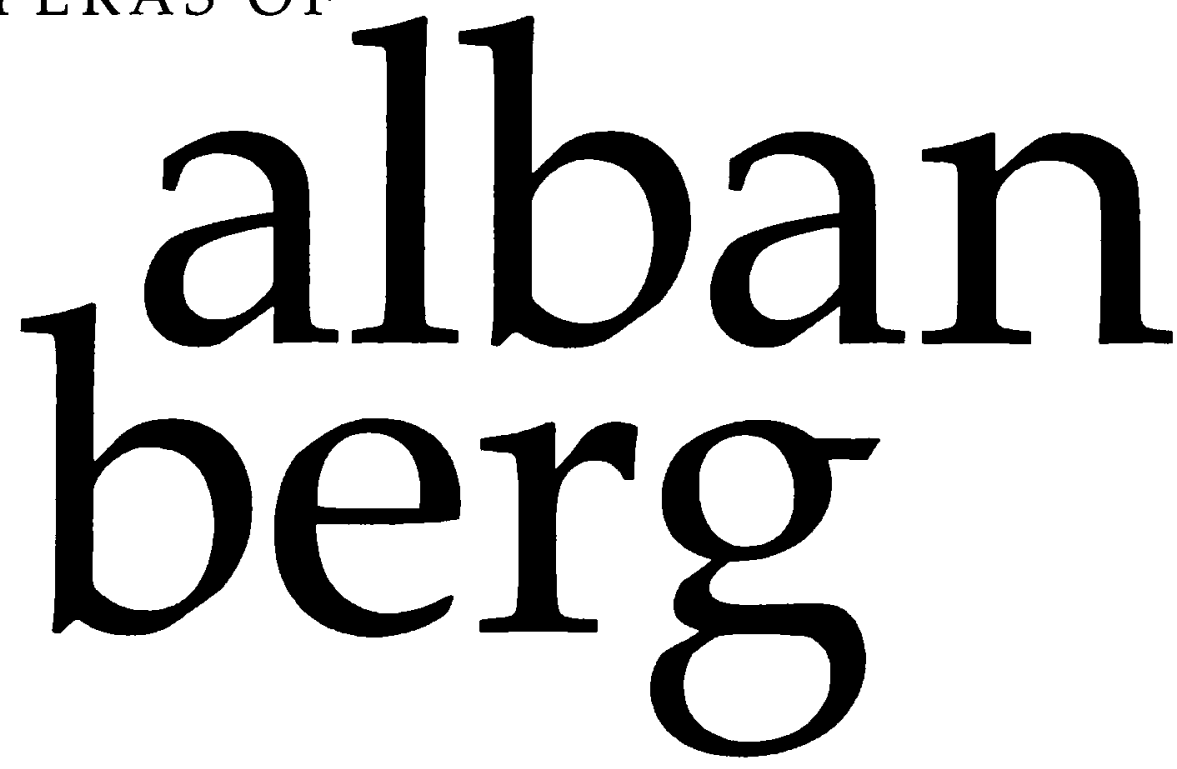

VOLUME TWO / LULU

\section{GEORGE PERLE}

UNIVERSITY OF CALIFORNIA PRESS

BERKELEY / LOS ANGELES / LONDON 
University of California Press, Berkeley and Los Angeles, California University of California Press, Ltd., London, England

(C) 1985 by The Regents of the University of California

Printed in the United States of America

ISBN 0-520-04502-5

$\begin{array}{lllllllll}1 & 2 & 3 & 4 & 5 & 6 & 7 & 8 & 9\end{array}$

Perle, George, 1915-

The operas of Alban Berg.

Bibliography: v. 1, p. 223-226; v. 2, p.

Includes index.

Contents: v. 1. Wozzeck - v. 2. Lulu.

1. Berg, Alban, 1885-1935. 2. Berg, Alban, 1885-1935. Wozzeck.

3. Berg, Alban, 1885-1935. Lulu.

I. Title.

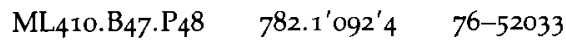

ISBN 0-520-03440-6 (v. 1) ISBN o-520-04502-5 (v. 2)

Illustration credits: Frontispiece and Number 2, Dr. Volker Scherliess. Numbers 1 and 17, Universal Edition, Vienna. Numbers $3,7,8,9,12$, and 13, Musiksammlung der Österreichische Nationalbibliothek and Universal Edition, Vienna. Number 4, Dorothea Robetin. Number 5, Wiener Stadt- und Landesbibliothek. Number 6, The New York Public Library. Number 10, The Library of Congress, Lawrence Schoenberg, and Helene Berg. Number 11, George Perle. Number 14, Zürcher Stadttheater. Number 15, Texaco Inc. Number 16, Dr. Friedrich Cerha. Numbers 18 and 19, Charles Patterson Van Pelt Library of the University of Pennsylvania and the Österreichische Musikzeitschrift. Numbers 20, 24, and 27, Herbert Reichner Verlag. Number 21, Erich Alban Berg. Number 22, Musiksammlung der Österreichische Nationalbibliothek. Numbers 23, 25, and 26, Louis Krasner. 